\title{
Prospective Observational Study of Weight- based Assessment of Sodium Supplements on Ultramarathon Performance (WASSUP)
}

\author{
Grant S. Lipman ${ }^{1 *}$ D, Tamara Hew-Butler², Caleb Phillips ${ }^{3}$, Brian Krabak and Patrick Burns ${ }^{1}$
}

\begin{abstract}
Background: Sodium supplements are ubiquitous in endurance running, but their impact on performance has been subjected to much debate. The objective of the study was to assess the effect of sodium supplementation as a weight-based predictor of race performance in ultramarathon runners.

Methods: Prospective observational study during an 80 km (50 mi) stage of a 6-stage $250 \mathrm{~km}$ (155 mi) ultramarathon in Chile, Patagonia, Namibia, and Mongolia. Finish line hydration status as measured by weight change, point-of-care serum sodium, and questionnaire provided sodium ingestion categories at 33rd percentile and 66th percentile both for weight-adjusted rate and total sodium consumption, then analyzed for significant relationships to race performance, dysnatremia, and hydration.
\end{abstract}

Results: Two hundred sixty-six participants were enrolled, with 217 (82\%) with complete sodium supplement rate data, 174 (80\%) with finish line sodium, and 161 (74\%) with both pre-race weights and total sodium ingestion allowing weight-based analysis. Sodium intake ranged from $131-533 \mathrm{mg} / \mathrm{h} / \mathrm{kg}(2-7.2 \mathrm{gm})$, with no statistically significant impact on pace, race time, or quintile rank. These outcomes did not change when sodium intake was analyzed as a continuous variable or by sub-group analysis of the 109 (68\%) normonatremic runners. When controlled for weight-adjusted sodium intake, performance was poorly correlated with hydration $(r=-0.152,95 \%$ $\mathrm{Cl}-0.348-0.057)$. Dehydrated runners outperformed those overhydrated, with $11 \%$ of top 25 th percentile finishers dehydrated (versus $2.8 \%$ overhydrated), with $3.6 \mathrm{~min} / \mathrm{km}$ faster pace and time $4.6 \mathrm{~h}$ faster finishing time.

Conclusions: No association was found between sodium supplement intake and ultramarathon performance. Dehydrated runners were found to have the best performance. This reinforces the message to avoid overhydration.

Keywords: Electrolytes, Supplements, Performance, Ultramarathon, Running, Endurance, Dehydration, Overhydration, Exercise-associated hyponatremia

\footnotetext{
* Correspondence: grantlip@hotmail.com

1 Department of Emergency Medicine, Stanford University School of

Medicine, 900 Welch Rd, Suite \#350, Palo Alto, CA 94304, USA

Full list of author information is available at the end of the article
}

\section{Springer Open}

(- The Author(s). 2021 Open Access This article is licensed under a Creative Commons Attribution 4.0 International License, which permits use, sharing, adaptation, distribution and reproduction in any medium or format, as long as you give appropriate credit to the original author(s) and the source, provide a link to the Creative Commons licence, and indicate if changes were made. The images or other third party material in this article are included in the article's Creative Commons licence, unless indicated otherwise in a credit line to the material. If material is not included in the article's Creative Commons licence and your intended use is not permitted by statutory regulation or exceeds the permitted use, you will need to obtain permission directly from the copyright holder. To view a copy of this licence, visit http://creativecommons.org/licenses/by/4.0/. 


\section{Key Points}

- Sodium supplement intake was not significantly associated with ultramarathon race pace, time to completion, or finishing rank.

- While performance was poorly correlated with hydration, dehydrated runners significantly outperformed those overhydrated, with a $3.6 \mathrm{~min} /$ $\mathrm{km}$ faster pace and $4.6 \mathrm{~h}$ faster finishing time.

- Sodium supplementation in ultramarathon runners was not associated with ultramarathon performance. Avoidance of overhydration may improve performance.

\section{Background}

The last decade has witnessed a worldwide $345 \%$ participation increase in ultramarathons, greater than the $49 \%$ increase in marathons [1], with $83-96 \%$ of long distance runners regularly ingesting sodium supplements during races [2]. The majority of endurance athletes believe that electrolyte supplementation is necessary to prevent muscle-cramping, nausea, and hyponatremia [3]. However, most studies fail to demonstrate associations between sodium intake and muscle cramps [4], or that supplements are protective against hyponatremia [2, 3, 5-7]. Since fluid consumption during exercise contributes more to hyponatremia than lack of sodium supplementation [8], the potential ergogenic benefits may be eclipsed by the risks of overhydration with sodium solution during endurance events $[6,9]$.

Serum sodium is a physiologically regulated variable, and sweat production during endurance exercise results in loss of this electrolyte in addition to total body water [10]. Inter-individual sweat sodium rate and composition varies widely, between 10 and $90 \mathrm{mmol} / \mathrm{L}$ [11]. The response to sodium over- and under-consumption are largely corrected by adaptive renal mechanisms [12], even in response to very low dietary sodium intakes [12, 13]. Additionally, there is evidence that extra-renal sodium storage and liberation occurs in both soft tissue and bone [14]. During periods of heat stress, it has been suggested that sweat sodium output changes in response to dietary intake [3] and sodium palatability increases [15]. These physiological mechanisms guard sodium homeostasis, which question the presumptive necessity of sodium supplementation during endurance exercise.

Sodium supplementation is targeted in many commercial products such as sports drinks, and included in nutritional sports guidelines [16, 17]. It is commonly believed that electrolyte supplementation is necessary during endurance exercise to maintain optimal fluid homeostasis and prevent performance decline [18, 19]. While total body water losses may impair performance in high intensity exercise [20], this has not been reflected in endurance exercise with larger fluid deficits [21]. There has been scant evidence supporting the performance benefit of sodium supplementation in endurance exercise or finishing status [22, 23]. Studies found no differences in triathlon race time between those taking salt tablets versus no electrolytes [5, 6, 24], no benefit of sodium concentrations on distances run in $4 \mathrm{~h}$ [25], or differences in race time in ultramarathon finishers versus small groups of runners with no electrolytes [26]. As only relatively small endurance running studies have investigated the impact of sodium supplementation on performance, an analysis of weight-based sodium ingestion rates in a larger cohort could provide further insight into this debate. The objective of the study was to assess the association of sodium supplementation as a weightbased predictor of race performance in ultramarathon runners. Our hypothesis was that there would be no significant associations between these variables.

\section{Methods \\ Setting}

This study was an analyses of data used to study the effect climate on dysnatremia during a prospective observational study during an $80 \mathrm{~km}(50 \mathrm{mi})$ 5th stage of a 6-stage $250 \mathrm{~km}(155 \mathrm{mi})$ ultramarathon in Chile and Patagonia (2017), and Namibia, Mongolia, and Chile (2018) [7]. All participants were offered the same amount of water for any given day [approximately $1.5 \mathrm{~L}$ per 10-12 km (6-7.5 mi)], had to carry all their own gear and at least $2000 \mathrm{kcal} /$ day (verified during registration), and did not receive any food beyond what they carried. As the races were of similar distances and required similar logistical and physical demands, they were combined for analyses [27-29].

\section{Research Design}

All entrants competing in a RacingThePlanet@ ultramarathon who could understand English were invited to participate in the study. During pre-race registration, informed consent was obtained and baseline demographics were recorded along with the runner's sodium supplementation type, rate, and ingestion strategy. The brand of sodium supplement was reviewed by the researchers to confirm the sodium concentration, and the amount of sodium was then calculated by the runner's supplementation intake rate and official finishing time (Supplementary datasheet). Stanford University School of Medicine institutional review board approved this study and it is in accordance with the ethical standards outlined in the Declaration of Helsinki.

Prior to the start of the $80 \mathrm{~km}(50 \mathrm{mi})$ stage of the race, body weight measurements (with shoes and running gear excluding backpack) were obtained with a battery-powered digital scale (SC-505 HoMedics; 
Commerce Tsp, MI) placed on a solid level surface. Immediately upon completion of the race at the finish line, study participants were re-weighed and an on-site analysis of serum sodium, blood urea nitrogen, and creatinine were obtained by point-of-care i-STAT (Abbott Point of Care, NJ) from finger-tip blood samples before post-race hydration could occur. Sodium intake rates were calculated by dividing the total sodium consumption by individual finishing time. Both the point-of-care device and the digital scale were calibrated prior to taking measurements.

\section{Participant Characteristics}

Participants were stratified into 33rd and 66th percentile based on the median data distribution, with categories of low sodium consumption $(<200 \mathrm{mg} / \mathrm{h} ;<2.79 \mathrm{mg} / \mathrm{h} / \mathrm{kg})$, moderate ( $200-360 \mathrm{mg} / \mathrm{h} ; 2.79 \mathrm{mg} / \mathrm{h} / \mathrm{kg}-4.78 \mathrm{mg} / \mathrm{h} / \mathrm{kg}$ ), or high (> $360 \mathrm{mg} / \mathrm{h} ;>4.78 \mathrm{mg} / \mathrm{h} / \mathrm{kg}$ ). Sodium consumption was also analyzed as a continuous variable. The following definitions were used: hypernatremia > $145 \mathrm{mmol} \mathrm{L}^{-}{ }^{1}$, normonatremia 135 to $\leq 145 \mathrm{mmol} \mathrm{L}^{-1}$, and hyponatremia $<135 \mathrm{mmol} \mathrm{L} \mathrm{L}^{-1}$. Hydration status was based upon body weight changes with $\geq 0 \%$ body weight change as overhydration, $<0$ to $-3 \%$ body weight change as euhydration, and $<-3 \%$ body weight change as dehydration [30]. The hot or cold climate category for each race was derived using methods fully described previously [7].

\section{Statistical Analysis}

Demographic and performance variables were analyzed for significant relationship to sodium consumption using one-way analysis of variance (ANOVA) for numeric variables and chi-squared for categorical variables. In the case of one-way ANOVA, the null hypothesis was that there was no significant difference between the mean values for performance and demographic variables between the different sodium consumption groups. Similarly, a chi-squared test was used to assess independence of the distribution of categorical variables from the sodium-based grouping. Both the characteristics of athletes and their performance were considered as main effects from the standpoint of sodium consumption. Lastly, Pearson's product-moment correlation was used to test for linear relationship between average pace and sodium consumption rate. To exclude the possibility that sodium may have imparted a different effect on higher or lower performing athletes, similarly paced runners performance were compared to their sodium consumption using Pearson's product-moment correlation. This analysis was performed with percentile-based performance groups (top 10\%, 11-25\%, 26-50\%, 51-75\%, and below 75\%) and using a sliding window method where sodium consumption and performance were compared between each athlete and the 19 other athletes with the closest performance. To ensure that those suffering deleterious health effects from dysnatremia would not bias outcomes, performance variables were also analyzed with those with dysnatremia removed. In this parallel analysis with normonatremic athletes, the same analysis of primary outcomes were analyzed using ANOVA, chi-squared, and Pearson's product-moment correlation to identify a potential relationship between sodium consumption and performance. As heat stress is known to increase thirst, sweating, and compensatory hydration requirements [30], ambient temperature could presumably impact sodium intake and subsequently effect performance. The average daytime temperature was $92.8^{\circ} \mathrm{F}\left(33.8{ }^{\circ} \mathrm{C}\right)$ for the hot races and $57.7^{\circ} \mathrm{F}\left(14.2^{\circ} \mathrm{C}\right)$ for the cold races [7], so race temperature both in absolute (average daytime temperature) and categorical (hot or cold) were included as a control variable in our analysis. To determine a potential difference in average temperature for sodium consumption groups, a Welch two-sample $t$ test was used. For categorical temperature (hot or cold), a chi-squared test was used. In either case, the tests were leveraged to assess the null hypothesis that sodium consumption would not differ significantly based on race temperature. Acceptable type 1 error was set to $5 \%($ alpha $=0.05)$ for interpretation of statistical tests, with 95\% confidence intervals. Univariate correlations and relationships were analyzed with Pearson's correlation coefficient and linear least squares regression. All analyses were performed with the statistical software R, version 4.0.

\section{Results}

There were 266 participants enrolled, 217 (82\%) with complete sodium supplement rate data, $174(80 \%)$ with post-race sodium measurements, and 161 (74\%) with both pre-race weights and sodium ingestion data. There were no significant differences in demographic variables between the sodium ingestion groups other than the low sodium category, which had a larger body mass index and run fewer ultramarathons compared to the two other sodium groups (Table 1). Sodium supplementation per weight-based intake rate $(\mathrm{mg} / \mathrm{h} / \mathrm{kg})$ did not have any statistically significant associations with hydration, dysnatremia, or race performance, among other variables (Table 2) This did not change with a non-weight-based analysis. [(mg/h), Supplementary Tables 1 and 2] When sodium intake rate was examined as a continuous variable, no significant associations were found with percentile rankings (Fig. 1).

Sodium intake in similarly paced runners was not significantly correlated with finishing quintile (Fig. 2). Controlling for dysnatremic runners, sub-group analysis of the 109 (68\%) normonatremic participants found no 
Table 1 Demographics by weight-based sodium intake

\begin{tabular}{|c|c|c|c|c|}
\hline Variable & $\begin{array}{l}\text { Low sodium intake Mean (SD); } \\
\text { Median (min-max) }\end{array}$ & $\begin{array}{l}\text { Medium sodium intake Mean (SD); } \\
\text { Median (min-max) }\end{array}$ & $\begin{array}{l}\text { High sodium intake Mean (SD); } \\
\text { Median (min-max) }\end{array}$ & $P$ value \\
\hline $\begin{array}{l}\text { Runner characteristics, } \\
n(\%)\end{array}$ & $53(32.9)$ & $53(32.9)$ & $55(34.2)$ & - \\
\hline Age, years & $45(8.4) ; 45$ (24-63) & $42(8.3) ; 42(23-56)$ & $41(9.2) ; 41$ (23-65) & 0.06 \\
\hline Sex & & & & 0.66 \\
\hline Female, $n(\%)$ & $15(28.3)$ & 19 (35.9) & $19(35)$ & \\
\hline Male, $n(\%)$ & $38(71.7)$ & $34(64.2)$ & $35(64.8)$ & \\
\hline Height, cm & $174(8.8) ; 175$ (157-188) & $177(8.1) ; 177$ (158-193) & $175(8.2) ; 177$ (160-195) & 0.3 \\
\hline Weight (starting), kg & $76(13.4) ; 74(52-106)$ & 73 (10.9); 74 (58-101) & 72 (10.5); 73 (52-94) & 0.26 \\
\hline $\mathrm{BMI}, \mathrm{kg} / \mathrm{m}^{2}$ & $25(3.3) ; 24(18-34)$ & $23(2.4) ; 23(19-31)$ & $23(2.7) ; 23(18-33)$ & 0.01 \\
\hline $\begin{array}{l}\text { Pack weight (starting), } \\
\text { kg }\end{array}$ & $10(2) ; 10(7-17)$ & $10(1.7) ; 10(8-15)$ & $10(1.8) ; 10(6-15)$ & 0.37 \\
\hline \# prior marathons & $13(15.2) ; 7(0-50)$ & 14 (28.8); 3 (0-130) & $7(9.6) ; 3(0-40)$ & 0.15 \\
\hline \# prior ultramarathons & $6(6.7) ; 5(0-35)$ & $11(14.3) ; 5(0-70)$ & $6(7.3) ; 4(0-40)$ & 0.02 \\
\hline $\begin{array}{l}\text { Running distance/week, } \\
\text { km }\end{array}$ & $72(35.4) ; 70(20-175)$ & $62(31) ; 60(16-160)$ & 81 (93.6); 60 (25-700) & 0.28 \\
\hline $\begin{array}{l}\text { Greatest running } \\
\text { distance/week, km }\end{array}$ & $131(75.8) ; 105$ (18-300) & $132(79) ; 105(20-300)$ & $144(133.1) ; 100(24-700)$ & 0.76 \\
\hline Longest single run & 121 (109); 88 (14-700) & $118(83.3) ; 100$ (12-400) & $117(72) ; 90(30-330)$ & 0.97 \\
\hline
\end{tabular}

Percentage of missing values from variables of sex, height, pack weight, prior marathons, prior ultramarathons, and training data $=<5 \%$ of data

significant differences in sodium intake and performance outcomes (Table 3).

There were 101 (56\%) runners enrolled from hot races and 60 (44\%) from cold races. Similarly paced participants were analyzed by sodium intake rate and separated by race temperatures, with no performance difference in hot versus cold environments (Fig. 3). When controlled for weight-adjusted sodium intake, performance was poorly correlated with hydration $(r=-0.152,95 \% \mathrm{CI}-$ $0.348-0.057)$. Dehydrated runners had improved performance compared to those overhydrated, with $11 \%$ of top 25th percentile finishers dehydrated (versus 2.8\% overhydrated), with $3.6 \mathrm{~min} / \mathrm{km}$ faster pace and $4.6 \mathrm{~h}$ faster race time (Table 4).

\section{Discussion}

This study found that neither the weight-based rate of sodium ingestion nor amount of sodium consumed over the duration of an $80-\mathrm{km}(50 \mathrm{mi})$ ultramarathon was associated with race performance as measured by average pace, race completion time, or finishing rank. These findings were consistent with prior endurance running research $[5,6,25,26]$. The total amount of ingested supplemental sodium of 2-7.2 g was comparable to prior studies on this subject $[5,6,25,26]$. Our study's primary outcome that sodium intake was not associated with running performance did not change when analyzed by similarly paced runners, controlled for dysnatremia, and when the runners were separated by extremes of temperature. This study provides further evidence that sodium supplementation is not an important contributor to ultramarathon race performance.

The main advantage of sodium supplementation-before, during, or after exercise-is plasma volume expansion [13], as fluids with sodium maintain plasma volume better than water alone during exercise [31]. However, we did not observe an impact of sodium intake rates on hydration levels. Rather, a strong inverse relationship has been seen between greater weight loss and improved performance in marathons [32], triathlons [33], adventure racing [34], and ultramarathons [27, 35, 36]. This was consistent with our observation that dehydrated runners, controlled for weight-adjusted sodium intake, out-performed the other runners. Conversely, those overhydrated ran slower and took over $4 \mathrm{~h}$ longer to complete the ultramarathon. It is theorized that loss of $3 \%$ total body weight represents physiologic euhydration, as this is the weight of water released with the oxidization of stored glycogen. It is reasonable that the larger glycogen stores used by faster runners resulting in better finishing times represent a portion of the weight loss used to define the hydration cohort. Sodium intake would not have a large impact on this relationship.

A popular misconception held by endurance athletes is that sodium supplementation will prevent the development of exercise-associated hyponatremia during endurance races [3]. Field data suggests that sodium supplementation does not prevent the development of 
Table 2 Post-race analysis by weight-based sodium intake

\begin{tabular}{|c|c|c|c|c|}
\hline Variable & $\begin{array}{l}\text { Low sodium intake Mean (SD); } \\
\text { Median (min-max) }\end{array}$ & $\begin{array}{l}\text { Medium sodium intake Mean (SD); } \\
\text { Median (min-max) }\end{array}$ & $\begin{array}{l}\text { High sodium intake Mean (SD); } \\
\text { Median (min-max) }\end{array}$ & $P$ value \\
\hline $\begin{array}{l}\text { Runner } \\
\text { characteristics, } n(\%)\end{array}$ & $53(32.9)$ & $53(32.9)$ & $55(34.2)$ & - \\
\hline $\begin{array}{l}\text { Body weight change, } \\
\mathrm{kg}\end{array}$ & $-4(7.9) ;-2(-50-2)$ & $-2(4.4) ;-2(-14-3)$ & $-4(5.5) ;-2(-17-2)$ & 0.24 \\
\hline Hydration & & & & 0.31 \\
\hline Dehydration, $n(\%)$ & $15(31.9)$ & $10(20)$ & $17(35.4)$ & \\
\hline Euhydration, $n(\%)$ & $18(38.3)$ & $23(46)$ & $22(45.8)$ & \\
\hline $\begin{array}{l}\text { Overhydration, } n \\
\text { (\%) }\end{array}$ & $14(29.8)$ & $17(34)$ & $9(18.8)$ & \\
\hline Serum sodium, mEq & $141(5.8) ; 140(126-158)$ & $140(6.3) ; 140(126-158)$ & $142(5.8) ; 140(133-160)$ & 0.38 \\
\hline Creatinine, mg/dL & $1(0.3) ; 1(0.5-1.8)$ & $1(0.5) ; 1(0.5-3.7)$ & $1(0.3) ; 1(0.1-1.8)$ & 0.62 \\
\hline $\begin{array}{l}\text { Sodium intake rate, } \\
\mathrm{mg} / \mathrm{h} / \mathrm{kg}\end{array}$ & $132(55.5) ; 122(25-235)$ & $269(66) ; 250(175-450)$ & $533(260.7) ; 450(267-1500)$ & $<0.01$ \\
\hline $\begin{array}{l}\text { Total sodium } \\
\text { ingested, } g\end{array}$ & $2(1.2) ; 2(0-6)$ & $4(1.6) ; 4(1-9)$ & $7(3.6) ; 7(3-18)$ & $<0.01$ \\
\hline Sodium diagnoses & & & & 0.64 \\
\hline $\begin{array}{l}\text { Hyponatremia, } n \\
\text { (\%) }\end{array}$ & $3(7.1)$ & $4(9.8)$ & $1(2.2)$ & \\
\hline $\begin{array}{l}\text { Hypernatremia, } n \\
\text { (\%) }\end{array}$ & $10(23.8)$ & $8(19.5)$ & $9(20)$ & \\
\hline $\begin{array}{l}\text { Normonatremia, } n \\
(\%)\end{array}$ & $29(69.1)$ & $29(70.7)$ & $35(77.8)$ & \\
\hline Temperature of races & & & & 0.81 \\
\hline Hot races, $n(\%)$ & $33(62.3)$ & $35(66)$ & $33(60)$ & \\
\hline Cold races, $n(\%)$ & $20(37.7)$ & $18(34)$ & $22(40)$ & \\
\hline Pace, $\mathrm{min} / \mathrm{km}$ & $11(3) ; 11(6-18)$ & $11(3.2) ; 10(6-20)$ & $10(3) ; 9(7-18)$ & 0.31 \\
\hline Total race time, $\mathrm{h}$ & $15(3.9) ; 15(8-23)$ & $14(4.2) ; 14(8-26)$ & $13(3.8) ; 12(9-23)$ & 0.28 \\
\hline Finishing rank, n (\%) & & & & 0.35 \\
\hline Top 10\% & $7(14.3)$ & $8(15.4)$ & $7(14.3)$ & \\
\hline $11-25 \%$ & $8(16.4)$ & $8(15.4)$ & $12(24.5)$ & \\
\hline $26-50 \%$ & $9(18.4)$ & $13(25)$ & $17(34.7)$ & \\
\hline $51-75 \%$ & $16(32.7)$ & 15 (28.9) & $6(12.2)$ & \\
\hline$>75 \%$ & $9(18.4)$ & $8(15.4)$ & $7(14.3)$ & \\
\hline
\end{tabular}

Percentage of missing values from pre-race weight $=26 \%$, hydration $=33 \%$, sodium and creatinine $=32 \%$, and rank $=11 \%$ ( $89 \%$ finished the races)

hyponatremia during triathlons when athletes drink ad libitum $[5,6]$. Sodium supplementation does, however, attenuate the decline in serum sodium when athletes drink to fully replace body weight losses [31], but does not prevent hyponatremia when athletes overdrink during exercise $[2,6,7,25,31,37]$. The observed rates of dysnatremia and normonatremia were very similar between sodium intake groups, despite disparate amounts of both weight-based and total ingested sodium. The pseudo-axiom that sodium supplements can "protect" against hyponatremia could be dangerous, as excess sodium intake can trigger osmoreceptor stimulation and thirst symptoms [26], resulting in increased fluid intake [38]. While there has been no reported exercise-induced hypernatremic fatalities from either profound water losses or exuberant sodium intake, the minimum lethal dose of salt (extrapolated from pediatrics) is $0.75-3 \mathrm{~g} / \mathrm{kg}$ body weight [39]. Our findings build on past investigations to help dispel the myth that sodium supplementation prevents the development of dilutional and/or symptomatic exercise-associated hyponatremia, which has been linked to over a dozen fatalities [8].

A limitation of these data are that sodium intake was calculated solely on the supplements ingested by the study participants. While the brand and sodium concentration of the supplements were confirmed by the researchers, exact amount of sodium ingested, dietary intake, sodium sweat rate, and plasma volume levels 


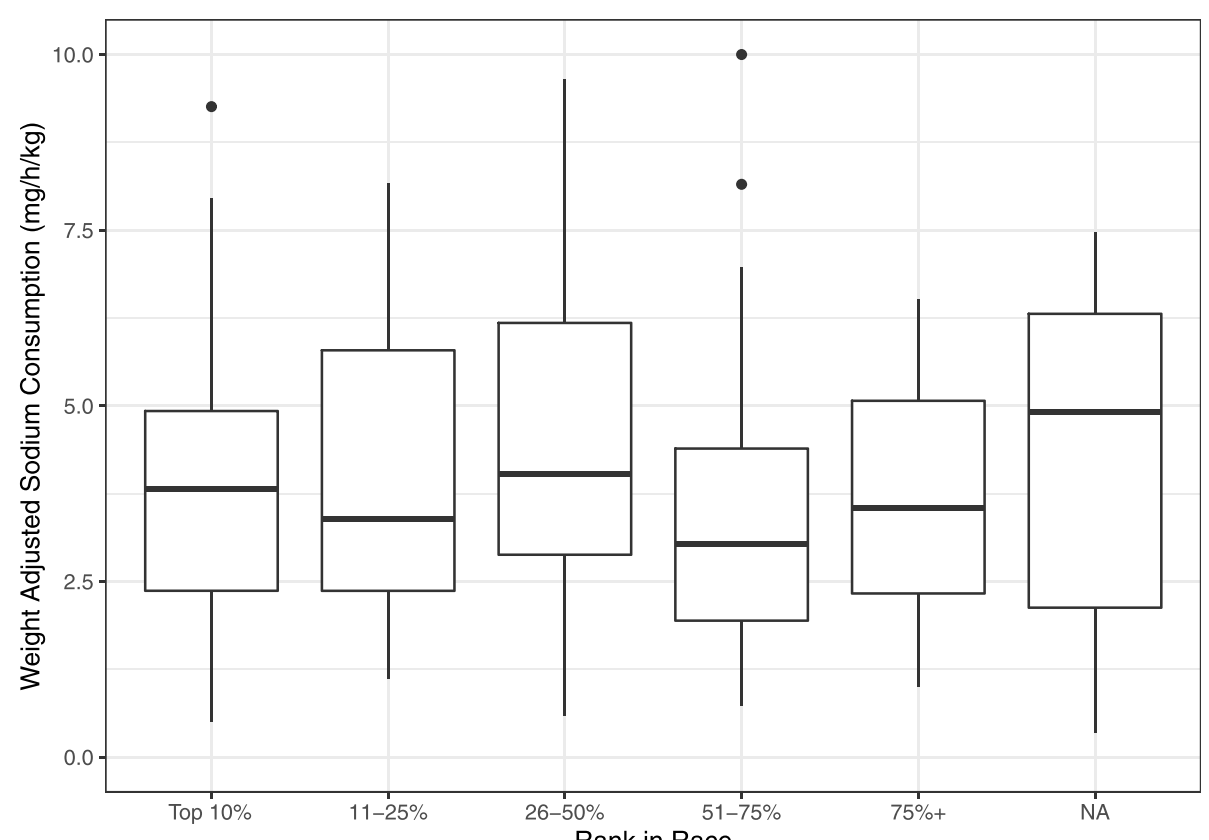

Fig. 1 Weight-adjusted sodium intake versus performance from percentile based groupings. Sodium intake does not appear significantly correlated with rank-based performance. Extreme outliers in sodium consumption (four values $>10$ ) were excluded to improve plot readability

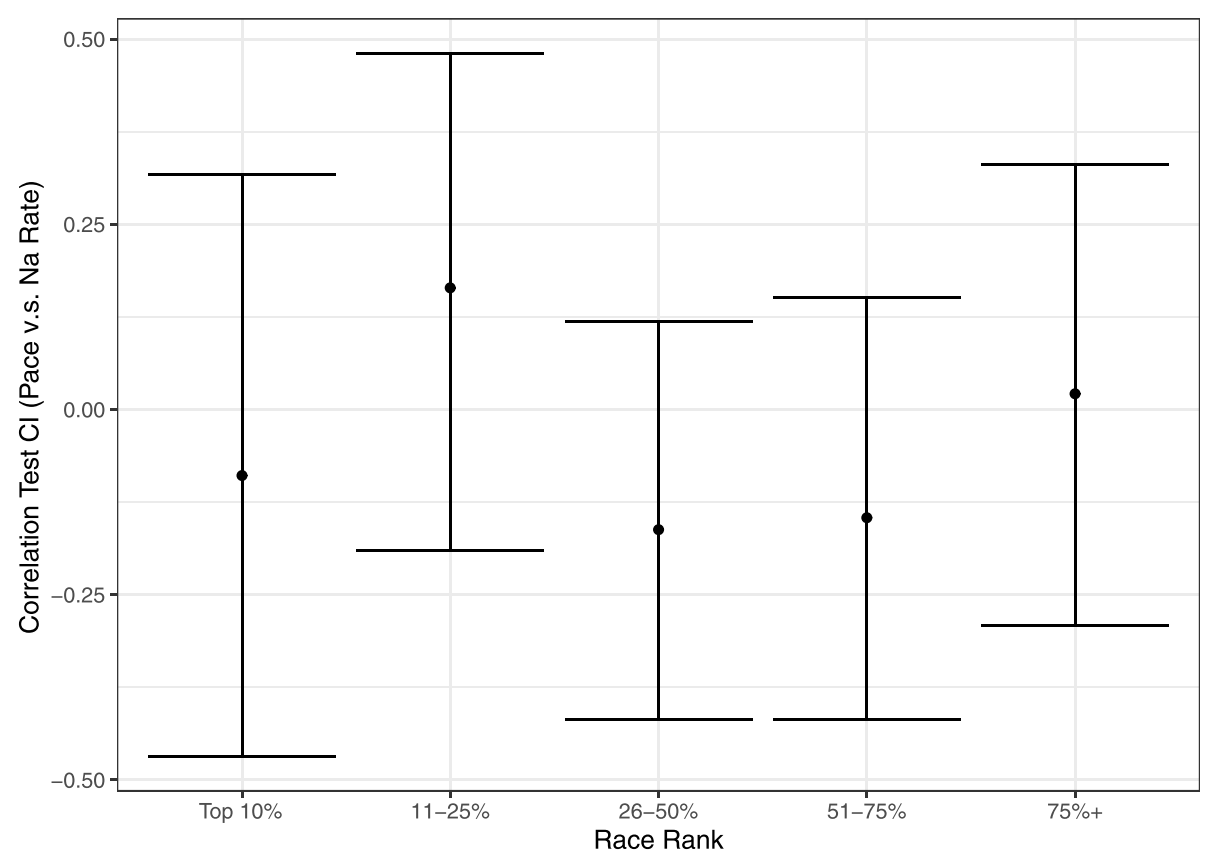

Fig. 2 Pearson's product moment-correlation coefficient and 95\% confidence interval for pace and sodium intake rate controlled for similar paced runners using percentile based grouping. 
Table 3 Post-race analysis by sodium intake in normonatremic participants

\begin{tabular}{|c|c|c|c|c|}
\hline Variable & $\begin{array}{l}\text { Low sodium intake Mean (SD); } \\
\text { Median (min-max) }\end{array}$ & $\begin{array}{l}\text { Medium sodium intake Mean (SD) } \\
\text { Median (min-max) }\end{array}$ & $\begin{array}{l}\text { High sodium intake Mean (SD); } \\
\text { Median (min-max) }\end{array}$ & $P$ value \\
\hline Runner characteristics, $n(\%)$ & $34(31.2)$ & $40(36.7)$ & $35(32.1)$ & - \\
\hline Body weight change, kg & $-3(4.2) ;-2(-14-2)$ & $-3(5.1) ;-2(-14-2)$ & $-5(5.8) ;-2(-16-2)$ & 0.44 \\
\hline \multicolumn{5}{|l|}{ Hydration } \\
\hline Dehydration, $n(\%)$ & $10(35.7)$ & $11(32.4)$ & $11(36.7)$ & \multirow[t]{3}{*}{0.82} \\
\hline Euhydration, $n(\%)$ & $11(39.3)$ & $13(38.2)$ & $14(46.7)$ & \\
\hline Overhydration, $n(\%)$ & $7(25)$ & $10(29.4)$ & $5(16.7)$ & \\
\hline Sodium intake rate, mg/h & $135(46.1) ; 129(40-200)$ & $266(51.7) ; 250$ (210-360) & 577 (264.8); 495 (370-1500) & $<0.01$ \\
\hline Total sodium ingested, $\mathrm{g}$ & $2(1) ; 2(1-4)$ & $4(1.1) ; 4(2-7)$ & $8(3.2) ; 7(3-18)$ & $<0.01$ \\
\hline Pace, min/km & $11(3.3) ; 11(6-18)$ & $11(3) ; 9(6-18)$ & $11(3.3) ; 10(7-18)$ & 0.85 \\
\hline Total race time, $\mathrm{h}$ & $15(4.3) ; 14(8-23)$ & $14(3.8) ; 12(8-23)$ & $14(4.2) ; 13(9-23)$ & 0.84 \\
\hline \multicolumn{5}{|l|}{ Finishing Rank, $n$ (\%) } \\
\hline Top 10\% & $4(12.1)$ & $5(12.8)$ & $3(8.8)$ & \multirow[t]{5}{*}{0.98} \\
\hline $11-25 \%$ & $4(12.1)$ & $7(18)$ & $7(20.6)$ & \\
\hline $26-50 \%$ & $9(27.3)$ & $11(28.2)$ & $10(29.4)$ & \\
\hline $51-75 \%$ & $9(27.3)$ & $8(20.5)$ & $6(11.7)$ & \\
\hline$>75 \%$ & $7(21.2)$ & $8(20.5)$ & $8(23.5)$ & \\
\hline
\end{tabular}

Percentage of missing values: hydration $=16 \%$, and rank $=3 \%$

were not determined; driven by logistical limitations that was consistent with prior ultramarathon research $[2,40]$. Exact amounts of sodium ingestion may have been inexact because of recall bias, but this was consistent across the entire study population. While weight was unable to be gathered on $26 \%$ of the study participants, this unlikely altered our conclusions as there was no difference in performance outcomes when sodium was analyzed as a non-weight-based predictor. Also, we did not gather information on injuries that could have impacted performance, and an injury log could provide further insight on this. To truly personalize sodium intake, sodium output could be quantified by sweat analysis and "matched" by intake, which warrants further investigation to determine if matched sodium intake could impact endurance running performance, particularly in events held in relatively hot conditions.

\section{Conclusions}

This study suggests that ad libitum sodium supplements in ultramarathon runners do not have any significant association with ultramarathon performance. Lower

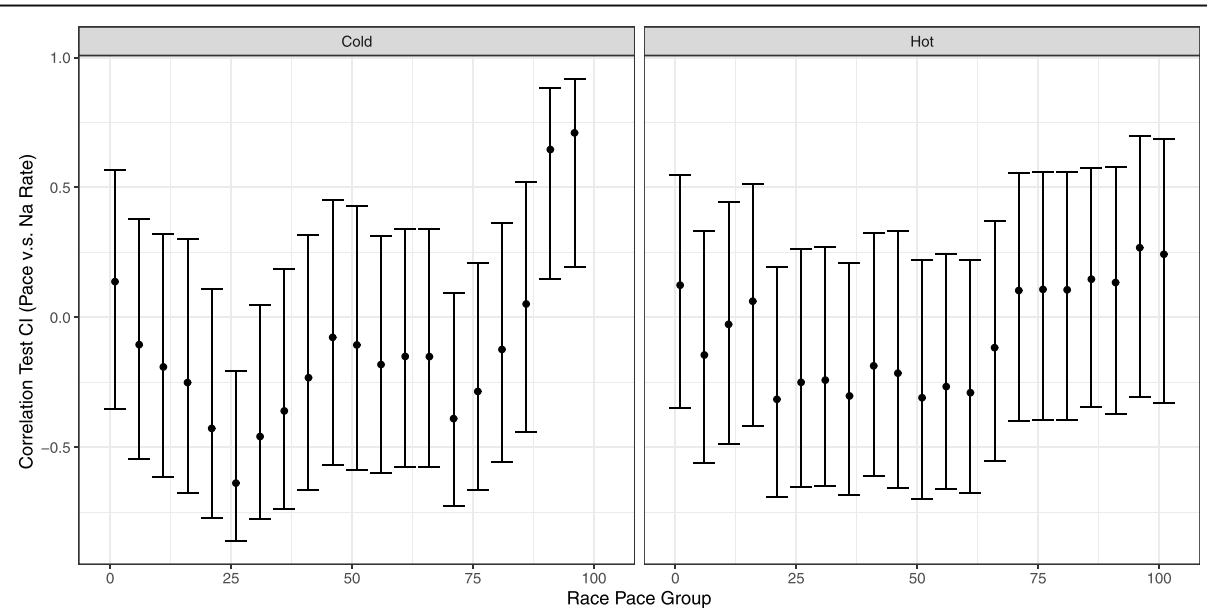

Fig. 3 Similar paced runners correlated with pace versus sodium intake in hot versus cold climates. This plot demonstrates a lack of overwhelming evidence for correlation between sodium intake and performance at any performance level. Each race pace group corresponds to a sliding window of the 20 runners with the most similar overall race performance according to average pace. Pearson's product moment correlation is used to assess linear relationship between pace and sodium intake. Each bar gives the correlation value and 95\% confidence interval 
Table 4 Hydration by sodium intake

\begin{tabular}{|c|c|c|c|c|}
\hline Variable & $\begin{array}{l}\text { Dehydration Mean (SD); } \\
\text { Median (min/max) }\end{array}$ & $\begin{array}{l}\text { Euhydration Mean (SD); } \\
\text { Median (min/max) }\end{array}$ & $\begin{array}{l}\text { Overhydration Mean (SD); } \\
\text { Median (min-max) }\end{array}$ & $P$ value \\
\hline Runner characteristics, n (\%) & $42(29.1)$ & $63(43.8)$ & $39(27.1)$ & \\
\hline Age, years & $45(7.4) ; 45(28-63)$ & $42(8.8) ; 43(23-65)$ & $42(9.5) ; 43(26-57)$ & 0.26 \\
\hline \multicolumn{5}{|l|}{ Sex } \\
\hline Female, $n(\%)$ & $16(38)$ & $16(25)$ & $12(31)$ & \multirow[t]{2}{*}{0.38} \\
\hline Male, $n(\%)$ & $26(62)$ & $47(75)$ & $27(69)$ & \\
\hline Height, cm & $176(7.7) ; 173(164-193)$ & 177 (8.4); 178 (158-189) & 175 (9.2); $177(157-195)$ & 0.53 \\
\hline Weight (starting), kg & $73(13.2) ; 72(52-103)$ & 75 (10.9); 74 (55-105) & 75 (11.3); 75 (57-107) & 0.59 \\
\hline $\mathrm{BMI}, \mathrm{kg} / \mathrm{m}^{2}$ & $24(2.9) ; 23(18-31)$ & $24(2.7) ; 24(20-33)$ & 25 (3.3); 24 (19-34) & 0.55 \\
\hline Pack weight (starting), kg & $9(2.1) ; 9(6-15)$ & $11(2.8) ; 10(7-17)$ & $13(3.4) ; 11(8-16)$ & $<0.01$ \\
\hline Body weight change, kg & $-10(7.6) ;-10(-50-3)$ & $-2(0.8) ;-2(-3-0)$ & $1(0.7) ; 1(0-2)$ & $<0.01$ \\
\hline Serum sodium, mEq & $141(4.3) ; 140$ (133-153) & $142(6.8) ; 140(124-160)$ & $139(5.4) ; 139$ (126-156) & 0.05 \\
\hline Sodium intake rate, mg/h & 323 (198.6); 280 (74-860) & 329 (264.3); $250(40-1500)$ & 279 (156.4); 240 (83-768) & 0.52 \\
\hline Total sodium ingested, g & $4(2.4) ; 4(1-9)$ & $4(3.5) ; 4(1-18)$ & $5(3.1) ; 4(1-14)$ & 0.53 \\
\hline \multicolumn{4}{|l|}{ Sodium diagnoses } & \multirow[t]{4}{*}{$<0.01$} \\
\hline Hyponatremia, n (\%) & $1(2.4)$ & $1(1.9)$ & $6(18.8)$ & \\
\hline Hypernatremia, $n(\%)$ & $8(19.5)$ & $14(26.4)$ & $4(12.5)$ & \\
\hline Normonatremia, $n(\%)$ & $32(78.1)$ & $38(71.7)$ & $22(68.8)$ & \\
\hline \multicolumn{4}{|l|}{ Temperature of races } & \multirow[t]{3}{*}{0.31} \\
\hline Hot races, $n(\%)$ & $19(45.2)$ & 49 (77.8) & $24(60)$ & \\
\hline Cold races, $n(\%)$ & $23(54.8)$ & $14(22.2)$ & $14(40)$ & \\
\hline Pace, min/km & $9(2.1) ; 9(6-14)$ & 11 (2.8); 10 (7-18) & $13(3.4) ; 13(6-20)$ & $<0.01$ \\
\hline Total race time, $\mathrm{h}$ & $12.4(2.9) ; 12(8-20)$ & $14(3.7) ; 13(9-23)$ & $17(4.3) ; 18(8-26)$ & $<0.01$ \\
\hline \multicolumn{4}{|l|}{ Finishing rank, n (\%) } & \multirow[t]{6}{*}{$<0.01$} \\
\hline Top 10\% & $8(20)$ & $9(14.5)$ & $4(10)$ & \\
\hline $11-25 \%$ & $8(20)$ & $18(29)$ & 0 & \\
\hline $26-50 \%$ & $14(35)$ & $17(27.4)$ & $6(15)$ & \\
\hline $51-75 \%$ & $7(17.5)$ & $13(21)$ & $14(35)$ & \\
\hline$>75 \%$ & $3(7.5)$ & $5(8.1)$ & $16(40)$ & \\
\hline
\end{tabular}

Percentage of missing values from: pre-race weight $=26 \%$, hydration $=33 \%$, sodium $=32 \%$, and rank $=11 \%$ ( $89 \%$ finished the races)

sodium intake rate and amount was not associated with exercise-associated hyponatremia, and higher sodium was not associated with exercise-induced hypernatremia. Dehydrated runners were found to have the best performance, with significantly faster pace and finishing times. This reinforces the message to avoid overhydration and not to agressively pursue electrolyte supplements to impact running performance.

\section{Supplementary Information}

The online version contains supplementary material available at https://doi. org/10.1186/s40798-021-00302-0.

Additional file 1:. Data Collection Questionnaire

Additional file 2: Supplementary Table 1. Demographics by sodium intake rate
Additional file 3: Supplement Table 2. Post-race analysis by sodium intake rate

\section{Abbreviations}

Km: Kilometers; Mi: Miles; Kcal: Kilocalories; Mg: Milligram; Kg: Kilogram; H: Hour; Mmol: Milimoles; L: Liter; Cm: Centimeters; M: Meters; mEq: Miliequivalents; dL: Decaliters; g: Grams; min: Minute; Cl: Confidence intervals; Mmol: Milimoles; SD: Standard deviation; Min: Minimum; Max: Maximum

\section{Acknowledgements}

We thank Drs. Colin Little, Keiran Warner, Nicky Mansfield, Jacob Jensen, Carrie Jurkiewicz, Brian Jarrett, and Anne Walker for their assistance with data collection. And thank you to Mary Gadams and RacingThePlanet@ staff for their support of scientific research. And to the athletes, your participation and enthusiasm for endurance running made this study possible.

\section{Authors' Contributions}

Study concept and design: GL, PB. Funding: GL. Study supervision: PB, GL, BL. Data analysis-integrity and accuracy: GL, PB, CP. Data analysis and 
interpretation: CP. Initial drafts: GL, THB. Critical revision and approval of the final manuscript: all authors.

\section{Funding}

The researchers were supported with a travel stipend by the 2017 and 2018 RacingThePlanet@ Research Grant. All materials loaned by Abbott were returned at the end of the study.

\section{Availability of Data and Materials}

The datasets used and analyzed during this current study are available from the corresponding author on reasonable request.

\section{Ethics Approval and Consent to Participate}

The Stanford University School of Medicine Institutional Review Board (IRB40456) approved this research. Informed consent was obtained after verbal and written explanation of the experimental design. The study was run in accordance with the standard of ethics for medical research outlined in the Declaration of Helsink

\section{Consent for Publication}

Not applicable.

\section{Competing interests}

The authors, Grant Lipman, Tamara Hew-Butler, Caleb Phillips, Brian Krabak, and Patrick Burns, declare that they have no competing interests.

\section{Author details}

${ }^{1}$ Department of Emergency Medicine, Stanford University School of Medicine, 900 Welch Rd, Suite \#350, Palo Alto, CA 94304, USA. Exercise and Sport Science, College of Education, Wayne State University, Detroit, MI, USA. ${ }^{3}$ Computational Science, University of Colorado, Boulder, CO, USA. ${ }^{4}$ Department of Orthopedics and Sports Medicine, University of Washington, Seattle, WA, USA.

Received: 5 October 2020 Accepted: 24 January 2021 Published online: 17 February 2021

\section{References}

1. Ronto P. The state of ultrarunning 2020: RunRepeatRun.com, IAU; 2020 [Available from: https://runrepeat.com/state-of-ultra-running.

2. Hoffman MD, Stuempfle KJ. Hydration strategies, weight change and performance in a $161 \mathrm{~km}$ ultramarathon. Res Sports Med. 2014;22(3):213-25

3. McCubbin AJ, Cox GR, Costa RJS. Sodium Intake Beliefs, Information Sources, and Intended Practices of Endurance Athletes Before and During Exercise. Int J Sport Nutr Exerc Metab. 2019;29(4):371-81.

4. Schwellnus MP, Nicol J, Laubscher R, Noakes TD. Serum electrolyte concentrations and hydration status are not associated with exercise associated muscle cramping (EAMC) in distance runners. Br J Sports Med. 2004;38(4):488-92.

5. Speedy DB, Thompson JM, Rodgers I, Collins M, Sharwood K, Noakes TD. Oral salt supplementation during ultradistance exercise. Clin J Sport Med. 2002:12(5):279-84

6. Hew-Butler TD, Sharwood K, Collins M, Speedy D, Noakes T. Sodium supplementation is not required to maintain serum sodium concentrations during an Ironman triathlon. Br J Sports Med. 2006;40(3):255-9.

7. Lipman GS, Burns P. Phillips C, Jensen J, Little C, Jurkiewicz C, et al. Effect of sodium supplements and climate on dysnatremia during ultramarathon running. Clin J Sport Med. 2020. https://doi.org/10.1097/JSM. 0000000000000832.

8. Hew-Butler T, Rosner MH, Fowkes-Godek S, Dugas JP, Hoffman MD, Lewis DP, et al. Statement of the Third International Exercise-Associated Hyponatremia Consensus Development Conference, Carlsbad, California, 2015. Clin J Sports Med. 2015;25(4):303-20.

9. Meyer LG, Horrigan DJ Jr, Lotz WG. Effects of three hydration beverages on exercise performance during 60 hours of heat exposure. Aviat Space Environ Med. 1995;66(11):1052-7.

10. Sterns RH. Disorders of plasma sodium--causes, consequences, and correction. N Engl J Med. 2015;372(1):55-65.

11. Baker LB, De Chavez PJD, Ungaro CT, Sopeña BC, Nuccio RP, Reimel AJ, et al. Exercise intensity effects on total sweat electrolyte losses and regional vs. whole-body sweat [Na(+)], [Cl(-)], and [K(+)]. Eur J Appl Physiol. 2019; 119(2):361-75.

12. Robinson S, Nicholas JR, Smith JH, Daly WJ, Pearcy M. Time relation of renal and sweat gland adjustments to salt deficiency in men. J Appl Physiol. 1955:8(2):159-65.

13. Luetkemeier MJ, Coles MG, Askew EW. Dietary sodium and plasma volume levels with exercise. Sports Med. 1997;23(5):279-86.

14. Titze J. A different view on sodium balance. Curr Opin Nephrol Hypertens. 2015;24(1):14-20.

15. Takamata A, Mack GW, Gillen CM, Nadel ER. Sodium appetite, thirst, and body fluid regulation in humans during rehydration without sodium replacement. Am J Physiol. 1994;266(5 Pt 2):R1493-502.

16. Thomas DT, Erdman KA, Burke LM. American College of Sports Medicine Joint Position Statement. Nutrition and Athletic Performance. Med Sci Sports Exerc. 2016:48(3):543-68.

17. Shirreffs SM, Sawka MN. Fluid and electrolyte needs for training, competition, and recovery. J Sports Sci. 2011:29(Suppl 1):S39-46.

18. Bailey E. Electrolytes: performance perks and real food sources NASM. org2017 [cited 2017 January 19]. Available from: https://blog.nasm.org/ fitness/electrolytes-performance-perks-and-real-food-sources.

19. Radloff M. 2019. [cited 2020]. Available from: https://www.maritaradloff.com/ blog/sodium-needs-for-endurance-athletes.

20. Adams JD, Sekiguchi Y, Suh HG, Seal AD, Sprong CA, Kirkland TW, et al. Dehydration Impairs Cycling Performance, Independently of Thirst: A Blinded Study. Med Sci Sports Exerc. 2018;50(8):1697-703.

21. Goulet ED. Effect of exercise-induced dehydration on time-trial exercise performance: a meta-analysis. Br J Sports Med. 2011;45(14):1149-56.

22. Currell $K$, Jeukendrup AE. Superior endurance performance with ingestion of multiple transportable carbohydrates. Med Sci Sports Exerc. 2008;40(2): 275-81.

23. Stuempfle KJ, Hoffman MD, Weschler LB, Rogers IR, Hew-Butler T. Race diet of finishers and non-finishers in a 100 mile $(161 \mathrm{~km})$ mountain footrace. J Am Coll Nutr. 2011;30(6):529-35.

24. Del Coso J, Gonzalez-Millan C, Salinero JJ, Abian-Vicen J, Areces F, Lledo M, et al. Effects of oral salt supplementation on physical performance during a half-ironman: A randomized controlled trial. Scand J Med Sci Sports. 2016; 26(2):156-64.

25. Twerenbold R, Knechtle B, Kakebeeke TH, Eser P, Müller G, von Arx P, et al. Effects of different sodium concentrations in replacement fluids during prolonged exercise in women. Br J Sports Med. 2003;37(4):300-3.

26. Hoffman MD, Stuempfle KJ. Does oral buffered sodium supplementation reduce nausea and vomiting during an ultramarathon? Res Sports Med. 2016;24(1):94-103.

27. Hoffman MD, Hew-Butler T, Stuempfle KJ. Exercise-associated hyponatremia and hydration status in 161-km ultramarathoners. Med Sci Sports Exerc. 2013;45(4):784-91.

28. Krabak BJ, Lipman GS, Waite BL, Rundell SD. Exercise-associated hyponatremia, hypernatremia, and hydration status in multistage ultramarathons. Wilderness Environ Med. 2017:28(4):291-8.

29. Lipman GS, Shea K, Christensen M, Phillips C, Burns P, Higbee R, et al. Ibuprofen versus placebo effect on acute kidney injury in ultramarathons: a randomised controlled trial. Emerg Med J. 2017;34(10):637-42.

30. Noakes TD, Sharwood K, Speedy D, Hew T, Reid S, Dugas J, et al. Three independent biological mechanisms cause exercise-associated hyponatremia: evidence from 2,135 weighed competitive athletic performances. Proc Natl Acad Sci USA. 2005;102(51):18550-5.

31. Barr SI, Costill DL, Fink WJ. Fluid replacement during prolonged exercise: effects of water, saline, or no fluid. Med Sci Sports Exerc. 1991:23(7):811-7.

32. Ebert TR, Martin DT, Bullock N, Mujika I, Quod MJ, Farthing LA, et al. Influence of hydration status on thermoregulation and cycling hill climbing. Med Sci Sports Exerc. 2007:39(2):323-9.

33. Sharwood KA, Collins M, Goedecke JH, Wilson G, Noakes TD. Weight changes, medical complications, and performance during an Ironman triathlon. Br J Sports Med. 2004;38(6):718-24

34. Wichardt E, Mattsson CM, Ekblom B, Henriksson-Larsén K. Rhabdomyolysis/ myoglobinemia and NSAID during $48 \mathrm{~h}$ ultra-endurance exercise (adventure racing). Eur J Appl Physiol. 2011;111(7):1541-4.

35. Wharam PC, Speedy DB, Noakes TD, Thompson JM, Reid SA, Holtzhausen $L M$. NSAID use increases the risk of developing hyponatremia during an Ironman triathlon. Med Sci Sports Exerc. 2006;38(4):618-22. 
36. Knechtle B, Knechtle P, Wirth A, Rust CA, Roseman T. A faster running speed is associated with a greater body weight loss in 100-km ultra-marathoners. J Sports Sci. 2012;30:1131-40.

37. Speedy D, Noakes T, Rogers IR. Hyponatremia in ultradistance triathletes. Med Sci Sports Exerc. 1999;31:809-15.

38. Cosgrove SD, Black KE. Sodium supplementation has no effect on endurance performance during a cycling time-trial in cool conditions: a randomised cross-over trial. J Int Soc Sports Nutr. 2013;10:30.

39. Royal College of Paediatrics and Child Health. The differential diagnosis of hypernatremia in children, with particular reference to salt poisoning - an evidenced-based guideline. 2009;1-106:9.

40. Hoffman MD, Stuempfle KJ. Sodium supplementation and exerciseassociated hyponatremia during prolonged exercise. Med Sci Sports Exerc. 2015;47(9):1781-7.

\section{Publisher's Note}

Springer Nature remains neutral with regard to jurisdictional claims in published maps and institutional affiliations.

\section{Submit your manuscript to a SpringerOpen ${ }^{\circ}$ journal and benefit from:}

- Convenient online submission

- Rigorous peer review

- Open access: articles freely available online

- High visibility within the field

- Retaining the copyright to your article

Submit your next manuscript at $\boldsymbol{\nabla}$ springeropen.com 